\title{
Catechin-incorporated dental copolymers inhibit growth of Streptococcus mutans
}

\author{
Alexandra MANKOVSKAIA ${ }^{1}$, Céline M. LÉVESQUE² ${ }^{2}$ Anuradha PRAKKI ${ }^{3}$
}

1- Undegraduate Student, Human Biology Department, Faculty of Dentistry, University of Toronto, Toronto, ON, Canada.

2- PhD, Associate Professor, Oral Microbiology Department, Faculty of Dentistry, University of Toronto, Toronto, ON, Canada.

3- DDS, MSc, PhD, Assistant Professor, Restorative Department, Faculty of Dentistry, University of Toronto, Toronto, ON, Canada.

Corresponding address: Anuradha Prakki - Restorative Department - University of Toronto - Faculty of Dentistry - Room 352C - 124 - Edward St. - Toronto - ON - Canada - M5G 1 G6 - Phone: 416-979-4932 - ext. 4389 - e-mail: anuradha.prakki@dentistry.utoronto.ca

Submitted: June 8, 2012 - Modified: March 12, 2013 - Accepted: March 12, 2013

\section{ABSTRACT}

\begin{abstract}
bjective: To test the inhibitory growth activity of green tea catechin incorporated into dental resins compared to resins containing the broad-spectrum antimicrobial compound chlorhexidine against Streptococcus mutans in vitro. Material and Methods: The minimum inhibitory concentrations (MICs) of epigallocatechin-gallate (EGCg) and chlorhexidine (CHX) were determined according to the microdilution method. Resin discs ( $5 \mathrm{~mm} \times 3 \mathrm{~mm}$ ) were prepared from Bis-GMA/TEGDMA (R1) and Bis-GMA/CH $\mathrm{CH}_{3}$ Bis-GMA (R2) comonomers $(n=9)$ containing: a) no drug, b) EGCg, c) CHX. Two concentrations of each drug (0.5x MIC and $1 x$ MIC) were incorporated into the resin discs. Samples were individually immersed in a bacterial culture and incubated for $24 \mathrm{~h}$ at $37^{\circ} \mathrm{C}$ under constant agitation. Cell viability was assessed by counting the number of colonies on replica agar plates. Statistical analysis was performed using one-way ANOVA, Tukey and Student t-tests $(\alpha=0.05)$. Results: Both resins containing EGCg and $\mathrm{CHX}$ showed a significant inhibition of bacterial growth at both concentrations tested $(p<0.05)$. A significantly higher inhibition was observed in response to resins containing $\mathrm{CHX}$ at $0.5 \times \mathrm{MIC}$ and $1 \times \mathrm{MIC}$, and $\mathrm{EGCg}$ at $1 \mathrm{x}$ MIC when compared to $\mathrm{EGCg}$ at $0.5 \times \mathrm{MIC}$. Also, EGCg at $0.5 x \mathrm{MIC}$ in $\mathrm{R} 1$ had a significantly higher growth inhibition than in R2. Conclusions: Both EGCg and $\mathrm{CHX}$ retained their antibacterial activity when incorporated into the resin matrix. EGCg at 1x MIC in R1 and R2 resins significantly reduced $S$. mutans survival at a level similar to $\mathrm{CHX}$. The data generated from this study will provide advances in the field of bioactive dental materials with the potential of improving the lifespan of resin-based restorations.
\end{abstract}

Key words: Chlorhexidine. Dental caries. Polymers. Catechin. Bis-GMA. Biomaterials.

\section{INTRODUCTION}

Dental caries is a multifactorial and transmissible disease that originates mainly from the interplay of oral flora, a susceptible host, and dietary factors. When organic acids are produced by the dental biofilm bacteria, they start diffusing through the enamel and cementum. As the acid diffuses into the tooth structure, it may find calcium deficient/ carbonate rich acid soluble minerals, and begins to dissolve it? ${ }^{7}$. When this process progresses long enough and reaches the dentin, the end result is tooth cavitation. The most common aetiological agents involved in this disease are Streptococcus mutans, followed by Streptococcus sobrinus,
Lactobacillus, and Actinomyces ${ }^{12}$. Consequently, caries prevention is based on the control of at least one of the mentioned causing factors.

The broad-spectrum antibacterial chlorhexidine $(\mathrm{CHX})$ is a very commonly used agent for the prevention or control of oral diseases. Studies have demonstrated that $\mathrm{CHX}$ is capable of arresting caries when applied to dentin ${ }^{3}$. However, $\mathrm{CHX}$ has some disadvantages, such as bacterial resistance, controversial efficacy against caries ${ }^{23,28}$ and toxicity to host tissues, motivating the investigation of alternatives ${ }^{2,21,24,31,32}$. Natural products, especially food extracts, have been shown to be good anticariogenic alternatives to synthetic chemicals ${ }^{8}$. The green tea polyphenol, epigallocatechin-gallate (EGCg) was found to inhibit acid production from 
dental plaque bacteria, while showing antimicrobial activity against $S$. mutans ${ }^{14,30,34}$. Moreover, EGCg was shown to inhibit the matrix metalloproteinase activities present in the dentin (MMP-2 and MMP-9) and associated with caries progression ${ }^{10}$.

Many properties of restorative dental composites have been improved in the past decades, including the mechanical properties, masticatory and abrasive wear resistance, esthetics, and bonding to the enamel and dentin. Bis-GMA (bisphenol glycidyl dimethacrylate) is still today the most commonly used monomer in composite resin formulations. It has very high viscosity, thus dilution with low viscosity alkoxyalkyl dimethacrylate esters, such as TEGDMA (triethyleneglycol dimethacrylate) is required to obtain adequate filler loading and handling characteristics ${ }^{5}$. Dilution with such a monomer, however, increases polymerization shrinkage and water sorption ${ }^{19}$. Thus, research has also been directed towards developing more hydrophobic and stable hydroxyl-free monomers with lower viscosities, such as $\mathrm{CH}_{3}$ bis-GMA (propoxylated bis-GMA) as a replacement for TEGDMA in resin formulations in order to reduce resin water sorption and polymerization shrinkage ${ }^{18}$.

It is therefore proposed that at this stage, advances of restoratives should happen towards the development of materials with bio-active functions, such as antibacterial activity to provide therapeutic effects $^{16}$. It could be assumed that the long-term durability of resin-dentin bonds and restorations may benefit from drug-loaded methacrylate-based polymeric materials, capable of releasing bioactive compounds. The aim of this study was to test the antimicrobial activity of EGCg when compared to $\mathrm{CHX}$, against the cariogenic organism S. mutans after being released by experimental dental copolymers. The null hypothesis to be tested is that different comonomers, incorporated drugs (CHX or EGCg) or drug ratios will not affect the growth of $S$. mutans.

\section{MATERIAL AND METHODS}

\section{Bacterial strain, growth condition, and chemicals}

The S. mutans UA159 strain isolated from a child with active caries was used in this study ${ }^{1}$. S. mutans was cultivated in Brain Heart Infusion (BHI) broth at $37^{\circ} \mathrm{C}$ in air with $5 \% \mathrm{CO}_{2}$. BHI broth agar plates were prepared using $1.5 \%(\mathrm{w} / \mathrm{v})$ agar. Bis-GMA, TEGDMA, the photosensitizer camphorquinone (CQ), reducing agent 2-(dimethylamino)ethyl methacrylate (DMAEMA), CHX diacetate salt hydrate (SigmaAldrich, St. Louis, MO, USA) and EGCg (Cayman Chemical Group, MI, USA) were all used as received. The Bis-GMA analog, $\mathrm{CH}_{3}$ Bis-GMA (2,2-bis[4-(2methacryloxyprop-1-oxy)phenyl]propane) was synthesized, purified, and stored according to the reported methods (Figures 1 a to $1 \mathrm{e})^{18}$. Briefly, bisphenol A was treated with propyleneoxide in the presence of $\mathrm{NaOH}$ and tetrahydrofuran (THF). The reaction product was isolated and then treated with 3 mols of methacryloyl chloride per mol of product, together with triethylamine in THF solvent to obtain $\mathrm{CH}_{3}$ Bis-GMA. The synthesized monomer was dissolved in deuterochloroform at $5 \%(w / v)$ and characterized by proton nuclear magnetic resonance $\left({ }^{1} \mathrm{H}\right.$ NMR; Varian Unity 400, $\left.400 \mathrm{MHz}\right)$ and carbon nuclear magnetic resonance $\left({ }^{13} \mathrm{C} N M R\right.$; General Electric GN500, $125 \mathrm{MHz}$ ) at $25^{\circ} \mathrm{C}$, providing spectra that were consistent with the expected product (Figure 1b).

\section{Minimum inhibitory concentration (MIC)}

Overnight cultures of $S$. mutans UA159 were diluted $(1: 20)$ into fresh BHI medium supplemented with different concentrations of drugs ( $\mathrm{CHX}: 1,2,5$, 10, 15, $25 \mu \mathrm{g} / \mathrm{mL}$; EGCg: 100, 250, 500, $1000 \mu \mathrm{g} /$ $\mathrm{mL}$ ) and incubated at $37^{\circ} \mathrm{C}$ for $24 \mathrm{~h}$. The cells were sonicated, serially diluted and, spot-plated onto BHI agar plates. Cell viability was assessed by counting colony forming units (CFUs). The minimum inhibitory concentration (MIC) test was performed according to the broth microdilution method using BHI broth as previously described ${ }^{29}$. Briefly, $\sim 10^{5} \mathrm{CFU} / \mathrm{ml}$ of bacterial cells were added to a 96 -well plate containing $\mathrm{BHI}$ medium supplemented with twofold serial dilutions of EGCg or CHX. Bacterial growth after $24 \mathrm{~h}$ was spectrophotometrically measured by using an ELISA microtiter plate reader (model

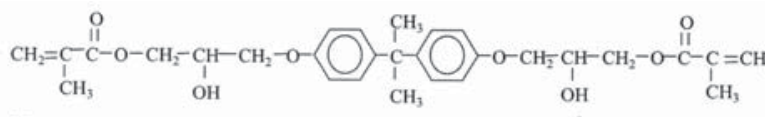<smiles>C=C(C)C(=O)OCC(C)COc1ccc(C(C)(C)c2ccc(OCC(C)COC(=O)C(=C)C)cc2)cc1</smiles>

(b)

(c)

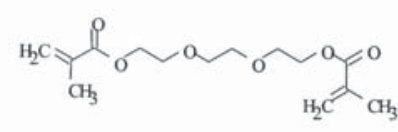

(d)

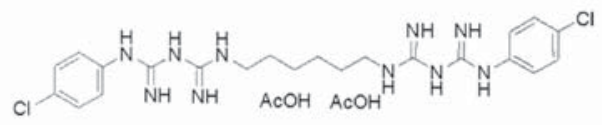

(e)

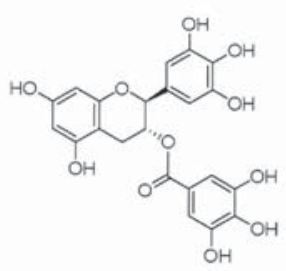

Figure 1- Molecular structure of Bis-GMA (a), $\mathrm{CH}_{3}$ BisGMA (b), TEGDMA (c), CHX (d), and EGCg (e) 
3550; Bio-Rad Laboratories, Richmond, CA) at an absorbance of $490 \mathrm{~nm}\left(\mathrm{OD}_{490}\right)$. Relative bacteria density percentages were calculated by using the following equation: $\left(\mathrm{OD}_{490}\right.$ of culture in the presence of each concentration of drug $) /\left(\mathrm{OD}_{490}\right.$ of culture in the absence of drug) $\times 100$. The MIC was determined as the lowest product concentration needed to ensure that the culture did not grow to over $10 \%$ of the relative bacterial cell density.

\section{Formulation of comonomers and specimen preparation}

The following two experimental resin formulations were prepared for this study: R1) Bis-GMA at 70 mol\% combined with TEGDMA at $30 \mathrm{~mol} \%$, or R2) Bis-GMA at 70 mol\% combined with $\mathrm{CH}_{3}$ BisGMA at $30 \mathrm{~mol} \%$. Except for the control groups (no drugs added), each formulation was randomly mixed with either $\mathrm{CHX}$ or EGCg at $0.5 x$ MIC or 1x MIC corresponding to drug concentrations in weight percentage, comprising a total of 10 groups $(n=9)$. Comonomers were activated for visible light polymerization by the addition of CQ and DMAEMA ( $0.2 \mathrm{w} / \mathrm{w} \%$ each). Specimens were fabricated inside a cylindrical acrylic matrix with internal dimensions of $5 \mathrm{~mm}$ diameter $\times 3 \mathrm{~mm}$ height. Unpolymerized material was sandwiched between two polyester strips over a glass-mixing tablet. Polymerization was done on both sides by a visible light curing unit (Demi LED, Kerr Co., WI, USA) for 40 s delivering uninterrupted $540 \mathrm{~mW} / \mathrm{cm}^{2}$, verified by a radiometer (Model 100, Demetron Research Co., CT, USA). Additional specimens were fabricated and the $24 \mathrm{~h}$ release rates of the drug loaded samples were tested spectrophotometrically as previously described ${ }^{22}$.

\section{Bacterial viability assay}

Overnight cultures of $S$. mutans UA159 were diluted $(1: 20)$ into $1.0 \mathrm{ml}$ of fresh BHI broth followed by the addition of one resin sample per test tube. The reaction mixtures were incubated at $37^{\circ} \mathrm{C}$ for 24 $\mathrm{h}$ under constant agitation. The next day, the cells were sonicated, and aliquots of $20 \mu$ l of each test tube were plated on $\mathrm{BHI}$ agar for CFU determination.
The colonies were counted after $48 \mathrm{~h}$ of incubation. The percentage of cell survival corresponded to the number of viable cells after treatment divided by the total number of viable cells in the untreated sample.

\section{Statistical analyses}

The data were shown to have normal distribution and equal variances (Kolmogorov-Smirnof test). The student $t$-test was applied to the bacterial cell viability data comparing each tested group with its respective control, and all R1 and R2 counterparts (same drug and drug ratio). One-way ANOVA followed by Tukey test was used for each resin to compare the bacterial cell viability among groups containing different drugs and ratios. The level of significance was set at 0.05 . Collected data were compiled and examined for relevance with the SPSS version 8.0 (SPSS Inc., Chicago, IL) statistical program.

\section{RESULTS}

The MICs of CHX and EGCg obtained using $S$. mutans UA159 strain were $2 \mu \mathrm{g} / \mathrm{mL}$ and $700 \mu \mathrm{g} /$ $\mathrm{mL}$, respectively. The $24 \mathrm{~h}$ drug release rates for $\mathrm{R} 1$ are: $\mathrm{CHX}\left(0.5 \times \mathrm{MIC}=1.28 \mu \mathrm{g} / \mathrm{cm}^{2}\right.$ and $1 \times \mathrm{MIC}=2.31$ $\left.\mu \mathrm{g} / \mathrm{cm}^{2}\right)$ and $\mathrm{EGCg}\left(0.5 \mathrm{x} \mathrm{MIC}=6.37 \mu \mathrm{g} / \mathrm{cm}^{2}\right.$ and $1 \mathrm{x}$ $\left.\mathrm{MIC}=13.05 \mu \mathrm{g} / \mathrm{cm}^{2}\right)$; and for R2 are: $\mathrm{CHX}(0.5 \mathrm{x}$ $\mathrm{MIC}=0.34 \mu \mathrm{g} / \mathrm{cm}^{2}$ and $1 \times \mathrm{MIC}=0.82 \mu \mathrm{g} / \mathrm{cm}^{2}$ ) and EGCg (0.5x MIC $=1.69 \mu \mathrm{g} / \mathrm{cm}^{2}$ and $1 \times \mathrm{MIC}=3.64$ $\left.\mu \mathrm{g} / \mathrm{cm}^{2}\right)$. The cell viability for drug-containing BisGMA/TEGDMA (R1) and Bis-GMA/ $\mathrm{CH}_{3}$ Bis-GMA (R2) is presented in Table 1 . The results demonstrated that both $\mathrm{CHX}$ and $\mathrm{EGCg}$ drugs retained their antimicrobial activity when integrated as part of R1 and $\mathrm{R} 2$ restorative materials. In each resin tested, there was no significant difference in bacterial growth inhibition between the treatment groups ( $\mathrm{CHX} \mathrm{0.5x}$ MIC, CHX 1x MIC, and EGCg 1x MIC), with the exception of EGCg at $0.5 x$ MIC that had significantly higher survival values $(p<0.05)$. Moreover, when comparing R1 and R2 incorporated with the same drug and drug ratio, no significant difference was found within the groups except for EGCg at 0.5x MIC in R1 that had a significantly lower percentage of

Table 1- Effect of drug-incorporated resins on S. mutans survival percentage

\begin{tabular}{cccccc}
\hline Groups & Control & CHX & CHX & EGCg & $\begin{array}{c}\text { EGCg } \\
\text { 1X MIC (s.d.) }\end{array}$ \\
\hline $\begin{array}{c}\text { Bis-GMA/ } \\
\text { TEGDMA } \\
\text { (R1) }\end{array}$ & $100^{\mathrm{Aa}}$ & $0.07(0.09)^{\mathrm{Bb}}$ & $0.0 \mathrm{~B}^{\mathrm{b}}$ & $29.05(12.16)^{\mathrm{Cc}}$ & $2.41(0.87)^{\mathrm{Be}}$ \\
$\begin{array}{c}\text { Bis-GMA/CH}{ }_{3} \mathrm{Bis}- \\
\text { GMA } \\
\text { (R2) }\end{array}$ & $100^{\mathrm{Aa}}$ & $0.30(0.16)^{\mathrm{Bb}}$ & $0.01(0.017)^{\mathrm{Bb}}$ & $52.38(18.33)^{\mathrm{Cd}}$ & $6.58(6.22)^{\mathrm{Be}}$ \\
\hline
\end{tabular}

*ANOVA and Tukey's test; $\alpha=0.05$; s.d.: standard deviation; Same upper case letters indicate no statistical difference within each line. Same lower case letters indicate no statistical difference within each column 
cell survival rate when compared to R2. The initially proposed null hypothesis is therefore rejected.

\section{DISCUSSION}

The controlled release of drugs or bioactive agents from polymers by Fickian diffusion, which is the spreading of solutes from regions of highest to regions of lower concentrations caused by the concentration gradient, has been the subject of research for many years ${ }^{27}$. In dentistry, $\mathrm{CHX}-$ containing resins have been successfully tested in terms of drug release and antibacterial activity. Most of these studies, however, use the agar plate method, where test samples are applied onto microorganisms inoculated at the surface of an agar plate. After appropriate incubation, the appearance and diameter of zones of growth inhibition around the test product indicate antimicrobial activity ${ }^{6,15,17}$. In this study, the drug-containing resins were immersed into a bacterial suspension of the cariogenic organism S. mutans, which better mimics the physiological conditions in vivo. Moreover, these conditions allowed the resin samples to absorb water, swell, and have drugs diffused toward the surrounding solution from all surfaces. We demonstrated that polymerized $\mathrm{R} 1$ and $\mathrm{R} 2$ resins can effectively release incorporated $\mathrm{CHX}$ and $\mathrm{EGCg}$, and that both drugs retain their antimicrobial activity upon incorporation into comonomers.

Drug release from resins is a process affected by many factors including, monomer type, degree of conversion, crosslinking density, drug type and concentration, and extracting media ${ }^{15,26}$. Therefore, the fact that $\mathrm{R} 1$ and $\mathrm{R} 2$ resins containing EGCg at $0.5 x$ MIC is less effective at inhibiting $S$. mutans growth compared to the EGCg at $1 x$ MIC is in part explained by the lower amount of drug diffusing through the polymer chains into the extracting nutrient-rich BHI medium. Although statistically significant only for $\mathrm{EGCg}$ at $0.5 \mathrm{x}$ MIC, lower cell survival rates were generally observed in response to R1 treatment groups compared to the R2 counterparts. The $\mathrm{CH}_{3}$ Bis-GMA analog exhibits higher hydrophobicity compared to Bis-GMA due to the absence of hydrogen bonding in the system as a result of the $-\mathrm{OH}$ substitution for the $-\mathrm{CH}_{3}$ group. Conversely, TEGDMA is a very hydrophilic monomer due to the presence of linear ether linkages ${ }^{25}$ (Figure $1 \mathrm{a}, 1 \mathrm{~b}, 1 \mathrm{c})$. As water penetrates more efficiently into the R1 matrix leading to larger expansion of voids between the polymer chains, more elutable species including the incorporated drugs were likely extracted from these samples leading to higher bacterial growth inhibition. The fact that the more hydrophobic resin $\left(\mathrm{CH}_{3}\right.$ Bis-GMA-based) released less amounts of drugs in the given time range of $24 \mathrm{~h}$, may suggest extended release in the long term ${ }^{21}$.
Long term release studies should be carried out in order to verify this premise.

The MIC values for $\mathrm{CHX}$ and EGCg against S. mutans obtained in this study were within reference ranges; $0.25-4.0 \mu \mathrm{g} / \mathrm{mL}$ for $\mathrm{CHX}^{9,20}$ and 31.25 $625 \mu \mathrm{g} / \mathrm{mL}$ for $\mathrm{EGCg}^{34}$, depending on the bacterial strain and culture medium. After $24 \mathrm{~h}$ of incubation in the presence of drug-incorporated monomers (at sub-MIC and MIC), we demonstrated that both drugs were released from the test comonomers and efficiently inhibited bacterial growth; $\mathrm{CHX}$ being the most effective. $\mathrm{CHX}$ is a bisguanide cationic broadspectrum antimicrobial compound, active against Gram-positive and Gram-negative bacteria. $\mathrm{CHX}$ electrostatically binds to the negatively charged bacterial surface and then forms pores or disrupts the membrane. At low concentrations, $\mathrm{CHX}$ has a bacteriostatic effect causing low molecular weight substances to leak out without damaging the cell irreversibly, while at high concentrations, $\mathrm{CHX}$ causes precipitation of cytoplasm exerting a bactericidal effect ${ }^{4,13}$.

There is still a lack of sufficient data and information on the antibacterial mode of action of catechins. It is, however, recognized that these compounds have binding affinities for serum proteins, which is shown by the decrease in antibacterial activity of tea in the presence of serum ${ }^{33}$. The fact that slightly higher MIC values of EGCg were obtained in this work compared to other studies also suggest that proteins present in the nutrient-rich $\mathrm{BHI}$ medium may bind to green tea catechins reducing their antimicrobial activities. This might also explain the lower growth inhibition values of EGCg in comparison to $\mathrm{CHX}$, despite the higher EGCg release results. Nevertheless, one could expect that the interactions of EGCg with proteins, causing significant distortion of their tertiary structure, may also account for the malfunction of certain bacterial enzymes. Interestingly, a study by $\mathrm{Xu}$, et al. ${ }^{34}$ (2011) demonstrated that EGCg inhibited biofilm formation of $S$. mutans which could be attributed to the interactions of EGCg with glucosyltransferase enzymes, thus disrupting the formation and integrity of the oral biofilm. More recently, Xu, et al. ${ }^{35}$ (2012) also demonstrated that EGCg suppresses the gtfB, gtfC, gtfD genes associated with extracellular polysaccharide formation of $S$. mutans. The potential anticariogenic activity of EGCg in clinical service clearly requires more research, since EGCg has been shown to interact with salivary proteins. Hara, et al. ${ }^{11}$ (2012) demonstrated that EGCg inhibited the activity of alpha-amylase by non-competitive inhibition, indicating that EGCg is effective at inhibiting the formation of fermentable carbohydrates involved in caries formation. 


\section{CONCLUSION}

Both EGCg and $\mathrm{CHX}$ retain their antibacterial activity when incorporated into the resin matrix. Although less effective at the sub-MIC level, EGCg in $\mathrm{R} 1$ and $\mathrm{R} 2$ resins significantly reduced cell survival of the cariogenic organism S. mutans, suggesting a novel alternative to synthetic chemicals. The evident antibacterial activity of EGCg suggest novel approaches in the development of dental restorative materials to help control dental caries, the most common infectious disease affecting humans.

\section{ACKNOWLEDGEMENTS}

This study was supported by funds from $U$ of $T$ College of Dentistry (Dental Research Institute) and MaRS Innovation Proof of Principle Program awarded to the principal investigator (AP).

\section{REFERENCES}

1- Ajdić D, McShan WM, McLaughlin RE, Savić G, Chang J, Carson MB, et al. Genome sequence of Streptococcus mutans UA159, a cariogenic dental pathogen. Proc Natl Acad Sci U S A. 2002;99:14434-9.

2- Bagis B, Baltacioglu E, Özcan M, Ustaomer S. Evaluation of chlorhexidine gluconate mouthrinse-induced staining using a digital colorimeter: an in vivo study. Quintessence Int. 2011;42:213-23. 3- Chaussain-Miller C, Fioretti F, Goldberg M, Menashi S. The role of matrix metalloproteinases (MMPs) in human caries. J Dent Res. 2006;85:22-32.

4- Davies A. The mode of action of chlorhexidine. J Periodontal Res Suppl. 1973;12:68-75.

5- Davy KW, Kalachandra S, Pandain MS, Braden M. Relationship between composite matrix molecular structure and properties. Biomaterials. 1998;19:2007-14.

6- Esteves CM, Ota-Tsuzuki C, Reis AF, Rodrigues JA. Antibacterial activity of various self-etching adhesive systems against oral streptococci. Oper Dent. 2010;35:448-53.

7- Featherstone JDB. Dental caries: a dynamic disease process. Aust Dent J. 2008;53:286-91.

8- Gazzani G, Daglia M, Papetti A. Food components with anticaries activity. Curr Opin Biotechnol. 2012;23:153-9.

9- Gronroos L, Matto J, Saarela M, Luoma AR, Luoma H, Jousimies-Somer $\mathrm{H}$, et al. Chlorhexidine susceptibilities of mutans streptococcal serotypes and ribotypes. Antimicrob Agents Chemoter. 1995;39:894-8.

10- Hannas AR, Pereira JC, Granjeiro JM, Tjäderhane L. The role of matrix metalloproteinases in the oral environment. Acta Odontol Scand. 2007;65:1-13.

11- Hara K, Ohara M, Hayashi I, Hino T, Nishimura R, Iwasaki Y, et al. The green tea polyphenol (-)-epigallocatechin gallate precipitates salivary proteins including alpha-amylase: biochemical implications for oral health. Eur J Oral Sci. 2012;120:132-9.

12- Hardie JM, Whiley RA. Plaque microbiology of crown caries. In: Newman HN, Wilson M, editors. Dental plaque revisited: oral biofilms in health and disease. Cardiff: Bioline; 1999. p. 283-94.

13- Henessey TS. Some antibacterial properties of chlorhexidine. J Periodontal Res Suppl. 1973;12:61-7.

14- Hirasawa M, Takada K, Otake S. Inhibition of acid production in dental plaque bacteria by green tea catechins. Caries Res. 2006;40:265-70.
15- Hirashi N, Yiu CK, King NM, Tay FR, Pashley DH. Chlorhexidine release and water sorption characteristics of chlorhexidineincorporated hydrophobic/hydrophilic resins. Dent Mater. 2008;24:1391-9.

16- Imazato S. Bio-active restorative materials with antibacterial effects: new dimensions of innovation in restorative dentistry. Dent Mater J. 2009;28:11-9.

17- Jedrychowski JR, Caputo AA, Kerper S. Antibacterial and mechanical properties of restorative materials combined with chlorhexidines. J Oral Rehabil. 1983;10:373-81.

18- Kalachandra S, Taylor DF, Deporter CD, Grubbs HJ, McGrath JE. Polymeric materials for composite matrices in biological environments. Polymer. 1993;34:778-82.

19- Kalachandra S, Turner DT. Water sorption of polymethacrylate networks: bis-GMA/TEGDM copolymers. J Biomed Mater Res. 1987;21:329-38.

20- Kang MS, Oh JS, Kang IC, Hong SJ, Choi CH. Inhibitory effect of methyl gallate and gallic acid on oral bacteria. J Microbiol. 2008;46:744-50.

21- Lessa FC, Nogueira I, Huck C, Hebling J, Costa CA. Transdentinal cytotoxic effects of different concentrations of chlorhexidine gel applied on acid-conditioned dentin substrate. J Biomed Mater Res B Appl Biomater. 2010;92:40-7.

22- Pallan S, Furtado Araujo MV, Cilli R, Prakki A. Mechanical properties and characteristics of developmental copolymers incorporating catechin or chlorhexidine. Dent Mater. 2012;28:68794.

23- Papas AS, Vollmer WM, Gullion CM, Bader J, Laws R, Fellows J, et al. Efficacy of chlorhexidine varnish for the prevention of adult caries: a randomized trial. J Dent Res. 2012;91:150-5.

24- Paraskevas S. Randomized controlled clinical trials on agents used for chemical plaque control. Int J Dent Hyg. 2005;3:162-78. 25- Prakki A, Cilli R, Vieira IM, Dudumas K, Pereira JC. Water sorption of $\mathrm{CH} 3-$ and $\mathrm{CF} 3-$ bis-GMA based resins with additives. J Appl Oral Sci. 2012;20:472-7.

26- Riggs PD, Braden M, Patel M. Chlorhexidine release from room temperature polymerizing methacrylate systems. Biomaterials. 2000;21:345-51.

27- Ritger PL, Peppas NA. A simple equation for description of solute release I. Fickian and non-fickian release from non-swellable devices in the form of slabs, spheres, cylinders or discs. J Control Release. 1987;5:23-36.

28- Slot DE, Vaandrager NC, Van Loveren C, Van Palenstein Helderman WH, Van der Weijden GA. The effect of chlorhexidine varnish on root caries: a systematic review. Caries Res. $2011 ; 45: 162-73$.

29- Suntharalingam $P$, Senadheera MD, Mair RW, Lévesque CM, Cvitkovitch DG. The LiaFSR system regulates the cell envelope stress response in Streptococcus mutans. J Bacteriol. 2009;191:2973-84. 30- Taylor PW, Hamilton-Miller JM, Stapleton PD. Antimicrobial properties of green tea catechins. Food Sci Technol Bull. 2005;2:7181.

31- Thomas L, Maillard JY, Lambert RJ, Russell AD. Development of resistance to chlorhexidine diacetate in Pseudomonas aeruginosa and the effect of a "residual" concentration. J Hosp Infect. 2000;46:297-303

32- Westergren G, Emilson CG. In vitro development of chlorhexidine resistance in Streptococcus sanguis and its transmissibility by genetic transformation. Scand J Dent Res. 1980;88:236-43.

33- Yam TS, Shah S, Hamilton-Miller JM. Microbiological activity of whole and fractionated crude extracts of tea (Camellia sinesis), and of tea components. FEMS Microbiol Lett. 1997;152:169-74. 34- Xu X, Zhou XD, Wu CD. The tea catechin epigallatocatechin gallate suppresses cariogenic virulence factors of Streptococcus mutans. Antimicrob Agents Chemother. 2011;55:1229-36.

35- Xu X, Zhou XD, Wu CD. Tea catechin epigallocatechin gallate inhibits Streptococcus mutans biofilm formation by suppressing $\mathrm{gft}$ genes. Arch Oral Biol. 2012; 57:678-683. 